\title{
Fiscal decentralization, fiscal rules and fiscal discipline
}

\author{
Bilin Neyapti* \\ Bilkent University, Department of Economics, 06800 Ankara, Turkey
}

\section{H I G H L I G H T S}

- Institutions matter for fiscal decentralization $(F D)$ to achieve fiscal discipline.

- Fiscal rules (FR) are hypothesized to enhance the effectiveness of FD.

- Panel evidence show that the negative effect of FD on deficits increases with FR.

- Balanced-budget and expenditure rules enhance FD's effectiveness.

- Debt rules have a direct negative effect on deficits.

\section{A R T I C L E I N F O}

\section{Article history:}

Received 15 April 2013

Received in revised form

28 September 2013

Accepted 6 October 2013

Available online 22 October 2013

\begin{abstract}
A B S T R A C T
Fiscal decentralization $(F D)$ and fiscal rules $(F R)$ are institutional mechanisms that are implemented by varying degrees in increasing number of countries. This paper investigates empirically the effect of $F R$ on the effectiveness of $F D$ in achieving fiscal discipline. Panel evidence strongly supports that balanced budget and expenditure rules help $F D$ to achieve this goal, while debt rule has a direct disciplinary effect.
\end{abstract}

(C) 2013 Elsevier B.V. All rights reserved.

\section{JEL classification:}

E62

$\mathrm{H} 72$

$\mathrm{H} 77$

O2

Keywords:

Fiscal institutions

Fiscal decentralization

Fiscal rules

Budget deficits

\section{Introduction}

Fiscal decentralization (FD) is an institutional mechanism that ideally helps to reveal preferences of local citizens and, hence, facilitates effective local public good provision via increased transparency and accountability. The potential benefits of $F D$ have been studied widely following the seminal work of Oates (1972). Tanzi $(2000,2008)$ argues that structural and institutional conditions, particularly the country size and governance quality, affect the potential effectiveness of $F D$. Recent empirical studies have also reached a near-consensus that the positive effects of $F D$ hinge upon the level of institutional and economic development (see, for example, De Mello, 2000; King and Ma, 2001; Neyapti,

\footnotetext{
* Tel.: +90 312290 2030; fax: +90 2665140

E-mail address: neyapti@bilkent.edu.tr.
}

2004, 2010; Zhang, 2006; Adam et al., 2008; Bouton et al., 2008; Kyriacou and Sagales, 2009). This explains why earlier studies presented mixed evidence on the macroeconomic benefits (often focusing on growth or efficiency) of $F D$ (see, for example, Treisman, 2000; Fisman and Gatti, 2002; Jin and Zou, 2002; MartinezVazquez and McNab, 2006).

The absence of a supportive institutional environment, however, hinders FD's effectiveness in achieving allocational and distributional efficiency. When large horizontal and vertical imbalances exist and local governments do not face sufficient incentives to internalize the burden of local spending, $F D$ often fails to deliver its objectives. If fiscal policy guidelines and rules are not well defined or enforced at the aggregate level, decentralizing spending and revenue collection fails to deliver fiscal discipline. Duly, recent theoretical studies emphasize the important role that fiscal rules $(F R)$ play for $F D$ to attain the desired welfare gains. More specifically, they point at the role of rule-based transfer mechanisms and 
hard budget constraints to generate the incentives for local government efficiency (see, for example, Sanguinetti and Tomassi, 2004; Stowhase and Traxler, 2005; Akin et al., 2011).

Recent studies document the state of $F R$ around the world and highlight the importance of rule-based fiscal mechanisms in improving fiscal outcomes. ${ }^{1}$ Schaechter et al. (2012) point out that an increasing number of countries have adopted $F R$, and the significant role of crises on this trend. Budina et al. (2012) observe a negative relationship between FR and public debt. Litschig (2012) and Wyplosz (2012), on the other hand, caution about the manipulability of $F R$, indicating that rules without strong institutional backing and enforcement characteristics would not yield their intended goals; in particular, too strict rules are argued to be associated with weaknesses during implementation.

In view of the above, this paper presents an original empirical test of the hypothesis that FR play a significant role in the effectiveness of $F D$. Using the recent panel datasets on FD and $F R$, and controlling for the relevant structural and institutional characteristics, the hypothesis is tested for both expenditure and revenue decentralization. The empirical evidence indicate that balance budget rules, their formal enforcement procedures, and expenditure rules contribute to the effectiveness of $F D$ in achieving fiscal discipline, while debt rules have a direct effect.

The rest of the paper is organized as follows. Section 2 presents the model and the data sources that are utilized in testing the above stated hypothesis. Section 3 reports the findings and, finally, Section 4 concludes.

\section{Data and model specification}

We consider that the primary objective of $F D$ is fiscal discipline. The hypothesis tested here is that the effectiveness of $F D$ in attaining fiscal discipline, measured by budget deficits, increases with the presence of fiscal policy rules. We employ the most recent and extensive panel data on $F D$ (expenditure and revenue decentralization, denoted by FDexp and FDRev, respectively) provided by the World Bank. $^{2}$ The source of data on FR is the IMF, which, based on formal and objective evaluation criteria, classifies $F R$ as balanced budget $(B B R)$; debt $(D R)$; expenditure $(E R)$; and revenue $(R R)$ rules. $^{3}$

To test the hypothesis that $F R$ enhances the effectiveness of $F D$, consider the following regression model:

$\operatorname{Def}_{i t}=a+b D e f_{i t-1}+c F D_{i t}+d F R_{i t}+e F R_{i t} * F D_{i t}+f Z_{i t}+\varepsilon_{i t}$

where the subscript it represents the country $(i)$-year $(t)$ observations, and Def is the ratio of budget deficits to GDP. $Z$ represents the set of control variables used commonly in the related literature, namely the government size ( $G$, measured as the share of overall government spending in GDP), rate of economic growth ( $g r$, measured as the percentage change in real GDP), governance (gov); and

\footnotetext{
1 Alesina and Bayoumi (1996) discuss the benefits of $F R$ for US budgeting. While Ma (1997) discusses the pros and cons of different fiscal transfer rules, Shah (2006) discusses the pros and cons of different agent types in charge of designing institutions, which govern fiscal grants.

2 Various studies have pointed out the problems related to a consistent measurement of FD across countries (see, for example, Dziobek et al., 2011 and Martinez-Vazquez and Timofeev, 2009). We use the cash-based shares of subnational government expenditures and revenues, published online by the World Bank (2012).

3 The FR dataset is composed of de jure numerical targets that have a minimum coverage of central government. Appendix provides the common set of countries, for which data on FR and the enforcement dummies (source: IMF, Fiscal Rules Dataset 2012) and the FD are both available.
}

the country size (measured by the log of population: $\log (p o p)) .{ }^{4}$ The rationale for these controls is as follows. Large governments can be associated with low fiscal discipline, hence $G$ is expected to have a positive effect on deficits; gr accounts for business cycles and is expected to have a negative association with deficits that tend to be counter-cyclical. By the very nature of its measurement criteria, ${ }^{5}$ gov is expected to be negatively associated with deficits. pop is a proxy for the heterogeneity in preferences that is one of the justifications for $F D^{6}$; since heterogeneity may also worsen the common pool problem and increase budgetary imbalances, however, we do not have a strong prior on the sign of this variable. The main hypothesis of the paper states that FD itself may not be negative or significant (see, for example, Thiessen, 2003; Neyapti, 2010); given the possible nonlinear effects of $F D$ we use it in logs to test this hypothesis.

Our null hypothesis is that it is not necessarily $c$ or $d$, but it is $e$ that is significantly negative in the above model; that is, FD may not achieve fiscal discipline if $F R$ are not in place. In addition to the interactions between $F D$ and $F R$, we also report the interactions of $F R$ with a dummy variable that stands for the legal enforcement of FR: Enforce. ${ }^{7}$ Given the autoregressive structure of deficits, the estimation involves the lagged values of Def.

The model is estimated using an unbalanced panel with a total of 137 observations. ${ }^{8}$ The estimation of the above model calls for several cautions. First, the presence of the lagged dependent variable renders the use of fixed or random effects inappropriate due to the violation of the assumption of exogenous covariates. ${ }^{9}$ Second, pooled OLS estimation is inconsistent if there are individual effects. The appropriate method therefore appears to be the dynamic panel data estimation with GMM instruments (AB-DPD), which yields consistent estimates (see Arellano and Bond, 1991). We also utilize this even though the use of the method reduces the number of observations to 34 .

\section{Estimation results}

As a preliminary, we investigate whether there is any significant difference in sample average Def before and after the implementation of (any type of) FR; we find that the answer is no. ${ }^{10}$ We next turn to the regression analysis to assess, in addition to the direct effect of FR on Def, its indirect effect via its impact on the effectiveness of $F D$.

\footnotetext{
4 World Bank indicators of governance cover control of corruption, government effectiveness, political stability, regulatory quality, government effectiveness, and voice and accountability.

5 We measure gov by averaging the six indices of governance (see Kaufmann et al., 2010): control of corruption; rule of law; political instability; governmental efficiency; voice and accountability; and regulatory quality.

6 See Neyapti (2010) for empirical evidence of the significant effect of pop on the effectiveness of $F D$.

7 We define Enforce as the sum of the enforcement dummies pertaining to all four types of rules provided in the FR-dataset (IMF) to account for its presence at large.

8 The cross section composition is well-balanced with eight transition economies, 10 developed and seven less developed countries. Descriptive statistics of the data is reported as follows:
}

$\begin{array}{llllllll} & \text { DEF } & \text { GR } & \text { gov } & \text { G } & \text { FDexp } & \text { FDrev } & \log (\text { pop }) \\ \text { Mean } & 0.91 & 3.49 & 0.40 & 27.48 & 28.40 & 24.48 & 16.43 \\ \text { Std. dev. } & 3.68 & 5.41 & 0.26 & 10.17 & 16.60 & 14.24 & 1.92 \\ \text { Maximum } & 16.9 & 15.8 & 0.86 & 51.76 & 60.30 & 53.20 & 20.90 \\ \text { Minimum } & -19.5 & -21.3 & 0.08 & 9.92 & 1.37 & 1.11 & 12.52\end{array}$

9 See, for example, Greene (2011)

10 Two years' averages are considered to maximize the number of observations before and after the adoption of a fiscal rule, leading to 65 and 53 observations, 
Table 1

Arellano-Bond estimates with robust errors (dependent variable: $D e f=$ Deficits/GDP).

\begin{tabular}{|c|c|c|c|c|c|c|}
\hline \multirow[t]{2}{*}{ FR-type: } & \multicolumn{3}{|l|}{ With FDexp } & \multicolumn{3}{|c|}{ With FDrev } \\
\hline & $B B R$ & $E R$ & $D R$ & $B B R$ & $E R$ & $D R$ \\
\hline $\operatorname{Def}(-1)$ & $\begin{array}{l}0.11 \\
(1.28)\end{array}$ & $\begin{array}{l}0.12^{* * * *} \\
(2.3)\end{array}$ & $\begin{array}{l}0.19^{* * * *} \\
(3.8)\end{array}$ & $\begin{array}{l}3.35^{* * * *} \\
(5.9)\end{array}$ & $\begin{array}{l}0.13^{* *} \\
(2.17)\end{array}$ & $\begin{array}{l}1.89^{* * * *} \\
(3.2)\end{array}$ \\
\hline$F R$ & $\begin{array}{l}0.20^{* * * *} \\
(3.13)\end{array}$ & $\begin{array}{l}0.59^{* * * *} \\
(4.3)\end{array}$ & $\begin{array}{l}-0.073^{* * * *} \\
(-12.01)\end{array}$ & $\begin{array}{l}0.18^{* * * *} \\
(3.1)\end{array}$ & $\begin{array}{l}-0.24^{*} \\
-(1.9)\end{array}$ & $\begin{array}{l}-0.06^{* * * *} \\
-(12.2)\end{array}$ \\
\hline Enforce ${ }^{*} F R$ & $\begin{array}{l}-0.17^{* * * *} \\
-(2.4)\end{array}$ & (Dropped) & (Dropped) & $\begin{array}{l}-1.37^{* * *} \\
-(2.1)\end{array}$ & (Dropped) & (Dropped) \\
\hline$F D$ & $\begin{array}{l}0.04^{* *} \\
(2.1)\end{array}$ & $\begin{array}{l}0.02^{* * *} \\
(2.9)\end{array}$ & $\begin{array}{l}0.003 \\
(0.2)\end{array}$ & $\begin{array}{l}3.89^{* * * *} \\
(8.5)\end{array}$ & $\begin{array}{l}0.03^{* * *} \\
(3.9)\end{array}$ & $\begin{array}{l}0.01 \\
(0.8)\end{array}$ \\
\hline$F D^{*} F R$ & $\begin{array}{l}-0.05^{* * *} \\
-(3.1)\end{array}$ & $\begin{array}{l}-0.02^{* * *} \\
-(4.3)\end{array}$ & $\begin{array}{l}0.02^{* * *} \\
(8.3)\end{array}$ & $\begin{array}{l}-4.83^{* * *} \\
-(3.1)\end{array}$ & $\begin{array}{l}5.75^{*} \\
(1.9)\end{array}$ & $\begin{array}{l}0.15^{* * * *} \\
(8.4)\end{array}$ \\
\hline$G$ & $\begin{array}{l}0.008^{* * *} \\
(4.3)\end{array}$ & $\begin{array}{l}0.008^{* * *} \\
(4.2)\end{array}$ & $\begin{array}{l}0.009^{* * *} \\
(16.4)\end{array}$ & $\begin{array}{l}0.71^{* * *} \\
(4.3)\end{array}$ & $\begin{array}{l}0.001^{* * *} \\
(4.2)\end{array}$ & $\begin{array}{l}0.01^{* * * *} \\
(17.2)\end{array}$ \\
\hline$g r$ & $\begin{array}{l}-0.001^{* * *} \\
-(3.1)\end{array}$ & $\begin{array}{l}-0.001^{* * *} \\
-(3.1)\end{array}$ & $\begin{array}{l}-0.198^{* * *} \\
-(7.5)\end{array}$ & $\begin{array}{l}-0.12^{* * *} \\
-(3.2)\end{array}$ & $\begin{array}{l}-0.001^{* * *} \\
-(3.3)\end{array}$ & $\begin{array}{l}-0.002^{* * *} \\
-(7)\end{array}$ \\
\hline Gov & $\begin{array}{l}0.02 \\
(0.2)\end{array}$ & $\begin{array}{l}-0.005 \\
-(0.1)\end{array}$ & $\begin{array}{l}3.565 \\
(0.43)\end{array}$ & $\begin{array}{l}0.05 \\
(0.5)\end{array}$ & $\begin{array}{l}-0.04 \\
-(0.4)\end{array}$ & $\begin{array}{l}3.67 \\
(0.39)\end{array}$ \\
\hline $\log (p o p)$ & $\begin{array}{l}-0.2^{* * * *} \\
-(3.07)\end{array}$ & $\begin{array}{l}-0.14^{* * * *} \\
(-2.84)\end{array}$ & $\begin{array}{r}-10.41^{* * *} \\
(-2.95)\end{array}$ & $\begin{array}{l}-0.21^{* * * *} \\
-(5.8)\end{array}$ & $\begin{array}{l}-0.24^{* * * *} \\
(-3.57)\end{array}$ & $\begin{array}{l}-0.12^{* * *} \\
-(3.4)\end{array}$ \\
\hline C & $\begin{array}{l}-3.22^{* * * *} \\
(-2.96)\end{array}$ & $\begin{array}{l}2.18^{* * * *} \\
(2.49)\end{array}$ & $\begin{array}{l}1.64^{* * * *} \\
(2.9)\end{array}$ & $\begin{array}{l}3.36^{* * *} \\
(5.9)\end{array}$ & $\begin{array}{l}4.06^{* * * *} \\
(3.7)\end{array}$ & $\begin{array}{c}1.89^{* * * *} \\
-(3.2)\end{array}$ \\
\hline Wald chi2(5) & $603^{* * *}$ & $22592^{* * *}$ & $1861^{* * *}$ & $148^{* * * *}$ & $700^{* * *}$ & $4636^{* * *}$ \\
\hline
\end{tabular}

Notes: Figures in parentheses are the $t$-ratios.

"Indicate significance at $10 \%$ levels.

*** Indicate significance at $5 \%$ levels.

*** Indicate significance at $1 \%$ levels.

Table 1 reports the results of the AB-DPD estimations with robust errors, using the alternative measurements of both $F D$ and $F R$. The instrument list is composed of the GMM instruments of the covariates besides the polity index, which is considered exogenous. ${ }^{11}$ The table shows that besides the lagged deficits term that exhibits significant persistence, some of our control variables are consistently significant with the expected sign: while $G$ has significant positive effect on budget deficits, $g r$ has a significant negative effect on Def. gov is not significant probably because FD, $F R$ and Enforce may already be capturing the effects of governance quality. The negative significance of pop possibly reflects the effect of other country-specific or trend elements, given this variable's relative persistence over the limited time dimension in a given country.

The main finding that provides support for the hypothesis of this paper is the interactive effect of $F D$ and $F R$, which is negative and significant in the case $F R=\{B B R, E R\}$ when used with expenditure decentralization. $D R$, however, has a direct effect on $D e f$ that is negative and significant, when used along with both FD types. When the model is estimated using revenue decentralization, the hypothesis is supported only in the case of $B B R$, although the direct effects of $D R$ and $E R$ are also negative and significant. ${ }^{12}$ Given

$\overline{\text { respectively. }}$

\begin{tabular}{lllllll} 
& Before & & \multicolumn{3}{l}{ After } \\
& Def & FDrev & FDexp & Def & FDrev & FDexp \\
Mean & -1.15 & 26.32 & 61.90 & -1.09 & 27.83 & 62.88 \\
Stdev & 15.7 & 248.1 & 493.8 & 12.3 & 218.8 & 525.9 \\
No of obs & 53 & 56 & 53 & 65 & 42 & 41 \\
Difference $t$-ratio & & & & 0.011 & 0.484 & 0.209
\end{tabular}

11 Polity measures the extent of democracy (source: Polity IV Database, Center for Systemic Peace).

12 Estimation cannot be performed for the case of $F R=R R$ due to insufficient data size (see the Appendix). the hypothesis of the paper, the mostly positive and significant direct effects on Def of both FDexp and FDrev should not come as a surprise; they indicate that FD generally fails to achieve fiscal discipline in the absence of $F R$. The coefficients of the interactions between $F R$ and the Enforce dummy are negative and significant for $F R=B B R$ in the cases of both FDexp and FDrev, while this interaction term is dropped due to collinearity for estimations using the rest of the FR terms.

The above findings are in support of the recent literature that stresses the important role of fiscal institutions for the effectiveness of $F D$ in delivering economic efficiency. It further presents original empirical evidence on the significant role of the centrally imposed budget constraints and debt rules, as well as the existence of fiscal rule enforcement procedures, in reaping the benefits of FD. ${ }^{13}$

\section{Conclusions}

Recent literature suggests that the effectiveness of FD in delivering fiscal efficiency depends on structural and institutional characteristics of a country. Using recent panel datasets of $F R$ and $F D$, this paper presents original evidence on the significant interactive effects of these variables on budget deficits. The evidence presented here indicate that the effectiveness of both expenditure and revenue decentralization on reducing budget deficits significantly depends on the existence of $F R$, particularly balanced-budget rules. Debt rules, on the other hand, have significant direct effects on fiscal discipline. While the current findings are based on a limited sample, they pose important policy advice for fiscal institutional design: countries that intend to decentralize their fiscal activities can increase their fiscal efficiency with the proviso that they also adopt $F R$ and improve their enforcement procedures.

\footnotetext{
13 A theoretical model developed by Akin et al. (2011) demonstrates the importance of budget rules for the efficiency of $F D$.
} 
Table A.1

Dummies for FR and enforcement by country-year observations. (cc stands for country codes, $y r$ are the enactment years of $F R$; source: IMF).

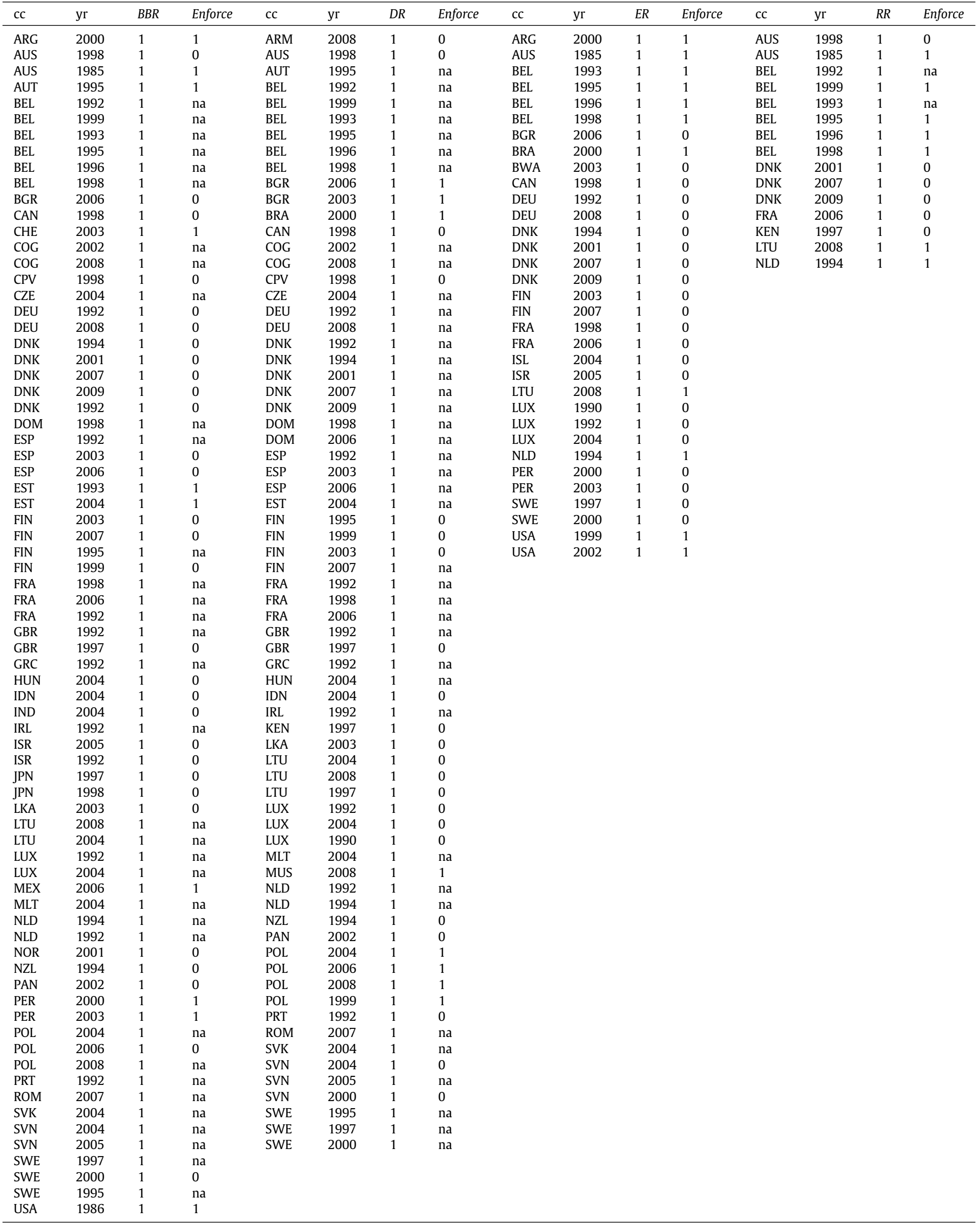




\section{Appendix}

See Table A.1.

\section{References}

Adam, A., Delis, M.D., Kammas, P., 2008. Fiscal decentralization and public sector efficiency: evidence from OECD countries. CESifo Working Paper Series 2364.

Akin, Z., Bulut-Cevik, Z.B., Neyapti, B., 2011. Does fiscal decentralization promote fiscal discipline? Bilkent University Discussion Paper 11-01.

Alesina, A., Bayoumi, T., 1996. The costs and benefits of fiscal rules: evidence from US States. NBER Working Paper 5614.

Arellano, M., Bond, S., 1991. Some tests of specification for panel data: Monte Carlo evidence and an application to employment equations. The Review of Economic Studies 58, 277-297.

Bouton, L., Gassner, M., Verardi, V., 2008. Redistributing income under fiscal vertical imbalance. European Journal of Political Economy 24, 7-328.

Budina, N., Kinda, T., Schaechter, A., Weber, A., 2012. Fiscal rules at a glance: country details from a new dataset. IMF Working Paper 12/273.

De Mello, L., 2000. Fiscal decentralization and intergovernmental fiscal relations: a cross- country analysis. World Development 28, 365-380.

Dziobek, C., Gutierrez Mangas, C., Kufa, P., 2011. Measuring fiscal decentralizationexploring the IMF's databases. IMF Working Paper WP/11/126.

Fisman, R., Gatti, R., 2002. Decentralization and corruption: evidence across countries. Journal of Public Economics 83, 325-545.

Greene, W.H., 2011. Econometric Analysis, seventh ed. Prentice Hall, NYU, New York.

Jin, J., Zou, H., 2002. How does fiscal decentralization affect aggregate, national, and subnational government size? Journal of Urban Economics 52, 270-293.

Kaufmann, D., Kraay, A., Mastruzzi, M., 2010. The worldwide governance indicators: a summary of methodology, data and analytical issues. World Bank Policy Research Working Paper No. 5430.

King, D.N., Ma, Y., 2001. Fiscal decentralization, central bank independence and inflation. Economic Letters 72, 95-98.

Kyriacou, A., Sagales, O.R., 2009. Fiscal decentralization and the quality of government: evidence from panel data. Hacienda Pública Española/Revista de Economía Pública 189, 131-155.
Litschig, S., 2012. Are rules-based government programs shielded from specialinterest politics? Evidence from revenue-sharing transfers in Brazil. Journal of Public Economics 96, 1047-1060.

Ma, J., 1997. Intergovernmental fiscal transfer: a comparison of nine countries, World Bank Economic Development Institute, Working Paper Series No. 1822.

Martinez-Vazquez, J., McNab, R.M., 2006. Fiscal decentralization, macrostability and growth. Hacienda Pública Española/Revista de Economía Pública 179, 25-49.

Martinez-Vazquez, J., Timofeev, A., 2009. Decentralization measures revisited International Center for Public Policy Working Paper Series, at AYSPS, GSU paper0913, Georgia State University.

Neyapti, B., 2004. Fiscal decentralization, Central Bank independence and inflation. Economics Letters 82, 227-230.

Neyapti, B., 2010. Fiscal decentralization and deficits: international evidence. European Journal of Political Economy 26, 155-166.

Oates, W., 1972. Fiscal Decentralization. Harcourt Brace Jovanowich, New York.

Sanguinetti, P., Tomassi, M., 2004. Intergovernmental transfers and fiscal behavior insurance versus aggregate discipline. Journal of International Economics 62, $149-170$

Schaechter, A., Kinda, T., Budina, N., Weber, A., 2012. Fiscal rules in response to crises- towards next-generation rules': a new dataset. IMF Working Pape $12 / 187$.

Shah, A., 2006. A practitioner's guide to intergovernmental fiscal transfers. World Bank, Working Paper WPS4039.

Stowhase, S., Traxler, C., 2005. Tax evasion and auditing in a federal economy. International Tax and Public Finance 12, 515-531.

Tanzi, V., 2000. On fiscal federalism: issues to worry about. In: Conference Notes, Conference on Fiscal Decentralization, IMF. Fiscal Affairs Department.

Tanzi, V., 2008. The future of fiscal federalism. European Journal of Political Economy 24, 7105-7112.

Thiessen, U., 2003. Fiscal decentralization and growth in high-income OECD countries. Fiscal Studies 24, 237-274.

Treisman, D., 2000. Decentralization and the quality of government. Department of Political Science, University of California at Los Angeles, unpublished paper.

Wyplosz, C., 2012. Fiscal rules: theoretical issues and historical experiences, NBER Chapters, in: Fiscal Policy after the Financial Crisis, pp. 495-525.

Zhang, X., 2006. Fiscal decentralization and political centralization in China: implications for growth and inequality. Journal of Comparative Economics 34, 713-726. 